\title{
Evaluation of salivary flow in patients during head and neck radiotherapy
}

\section{Análise do fluxo salivar em pacientes durante a radioterapia em cabeça e pescoço}

\author{
Paulo Rogério Ferreti Bonan* \\ Fábio Ramoa Pires** \\ Márcio Ajudarte Lopes ${ }^{* * *}$ \\ Osvaldo Di Hipólito Jr***
}

\begin{abstract}
Radiotherapy is frequently employed for the treatment of head and neck squamous cell carcinoma. Among the side effects, xerostomia is one of the most important. With the objective of evaluating the role of radiotherapy in salivary flow, we performed three salivary sample collections: at the beginning of, during, and immediately after radiotherapy. The results showed that the salivary flow values of the first collection were very similar to those of the control group. However, during treatment, there was a significant decrease of the salivary flow $(p=0.0008)$, which continued low immediately after radiotherapy $(\mathrm{p}=0.0009)$. Our study showed that radiotherapy leads to an important reduction of salivary flow during and after radiotherapy.
\end{abstract}

DESCRIPTORS: Radiotherapy; Xerostomia; Squamous cell carcinoma.

\begin{abstract}
RESUMO: A radioterapia é um tratamento comumente empregado em pacientes portadores de carcinomas espinocelulares em cabeça e pescoço. Entre os efeitos colaterais locais, a xerostomia é um dos mais importantes. Com o objetivo de avaliar o efeito da radioterapia sobre o fluxo salivar, foram feitas 3 coletas salivares: no início, em um período intermediário e posteriormente ao tratamento radioterápico. Os resultados obtidos demonstraram médias de fluxo salivar semelhantes entre a coleta inicial e o grupo controle. Com o decorrer da radioterapia, houve diminuição significativa do fluxo salivar na coleta intermediária $(p=0,0008)$, que se manteve após o término da radioterapia $(p=0,0009)$. Nosso estudo enfatiza que há redução significativa do fluxo salivar durante e após a radioterapia.
\end{abstract}

DESCRITORES: Radioterapia; Xerostomia; Carcinoma espinocelular.

\section{INTRODUCTION}

The most important therapies for treatment of head and neck squamous cell carcinomas (HNSCC) are surgery and radiotherapy. Chemotherapy is restricted for HNSCC, and is generally employed in advanced tumors ${ }^{2}$.

Although radiotherapy is effective to control HNSCC, side effects are undesirable and may aggravate the patient's health status ${ }^{19}$. Alterations found in irradiated sites occur mainly in skin, mucosa, bones, salivary glands and teeth ${ }^{10,11,18}$. As a consequence, different grades of dermatitis and mucositis, bone and teeth alterations are observed. In salivary glands, atrophy and acinar degeneration caused by radiotherapy commonly result in a decreased saliva production, which is a frequent complaint of head and neck irradiated patients $^{6,9}$.
The severity of reduced salivary flow ranges from a little dryness complaint on a relatively normal mucosa to the total absence of saliva with severe mucosa burns ${ }^{6}$. With the reduction of salivary flow, which is observed at the beginning of treatment, other alterations may occur including an increase of salivary viscosity, $\mathrm{pH}$, ions and immunoglobulins levels ${ }^{13}$. As a consequence, irradiated patients often present higher risk for the development of dental caries and difficulties to swallow, speak and eat $\mathrm{t}^{1,4,7,12,17}$.

Although compensatory salivary production by non-affected salivary glands may exist, permanent salivary flow reduction is frequently found even one year after the end of the radiotherapeutic treatment. Reduction of salivary flow is strongly associated with the involvement of the parotid glands in the radiation field. The total dose is also

\footnotetext{
*Professor, Discipline of Oral and General Pathology, School of Dentistry, University of Alfenas.

** Professor, Discipline of Oral Pathology, School of Dentistry, State University of Rio de Janeiro.

*** Professors, Discipline of Semiology, School of Dentistry, State University of Campinas.
} 
Bonan PRF, Pires FR, Lopes MA, Hipólito Jr O Di. Evaluation of salivary flow in patients during head and neck radiotherapy. Pesqui Odontol Bras 2003;17(2):156-60.

important, and the greater harm is produced when doses reach over 44 grays $(\mathrm{Gy})^{14}$.

The aim of this study was to evaluate salivary flow alterations during head and neck radiotherapy applied to patients with squamous cell carcinoma and to compare them with the values obtained for the control group.

\section{MATERIAL AND METHODS}

This study included 47 patients divided in two groups. The research methodology was approved by the Ethical Research Committee, School of Dentistry of Piracicaba:

a) group I - (study group) - 22 patients attended at the Oral Diagnosis Clinic (OROCENTRO), School of Dentistry of Piracicaba, and at the
Radiotherapeutic Service, Sugar Cane Suppliers Hospital, Piracicaba, Brazil. The age of these patients ranged from 34 to 83 years, with an average of 58.5 years. There were 18 males $(82 \%)$ and four females $(18 \%)$. The majority of the patients $(90.9 \%)$ were white, and $9.1 \%$ were black. These patients presented squamous cell carcinomas and were submitted to head and neck radiotherapeutic treatment, alone or combined with surgery. Three non-stimulated salivary collections were performed for 5 minutes each: at the beginning of, during, and at the end of radiotherapy (Table 1 ).

b) group II - (control group) - 25 healthful patients. Of these patients, $20(80 \%)$ were males and 5 $(20 \%)$ were females. The average age was 59.24 years, ranging from 42 to 78 years. The control

TABLE 1 - Distribution of patients (group I) according to age, gender, skin color, tumor site, clinical stage and radiotherapeutic total dose (RTD).

\begin{tabular}{|c|c|c|c|c|c|c|}
\hline Patients & Age & " Gender & "Skin Color & Tumor site & Clínical stage & PIRD (Gy) \\
\hline 1 & 58 & $\mathrm{M}$ & B & Floor of the mouth & IV & 81 \\
\hline 2 & 61 & M & $\mathrm{W}$ & Floor of the mouth & III & 71 \\
\hline 3 & 75 & M & $\mathrm{W}$ & Tongue & III & 70 \\
\hline 4 & 58 & M & W & Alveolar ridge & IV & 82.6 \\
\hline 5 & 74 & $\mathrm{M}$ & $\mathrm{W}$ & Tongue & IV & 70 \\
\hline 6 & 83 & $\mathrm{M}$ & $\mathrm{W}$ & Floor of the mouth & III & 72 \\
\hline 7 & 58 & M & $\mathrm{W}$ & Tongue & III & 71 \\
\hline 8 & 62 & M & $\mathrm{W}$ & Pyriform sinus & IV & 71 \\
\hline 9 & 49 & $\mathrm{M}$ & $\mathrm{W}$ & Cervical metastasis (unknown primary) & IV & 60 \\
\hline 10 & 52 & M & $\mathrm{W}$ & Tongue & II & 70 \\
\hline 11 & 47 & M & $\mathrm{W}$ & Pyriform sinus & IV & 80 \\
\hline 12 & 56 & $\mathrm{~F}$ & $\mathrm{~W}$ & Tonsil & IV & 57 \\
\hline 13 & 46 & $\mathrm{M}$ & $\mathrm{W}$ & Tongue & IV & 68.4 \\
\hline 14 & 34 & $\mathrm{~F}$ & $\mathrm{~W}$ & Retromolar & IV & 58.8 \\
\hline 15 & 46 & M & $\mathrm{W}$ & Pyriform sinus & III & 70.4 \\
\hline 16 & 64 & M & $\mathrm{W}$ & Oropharynx & IV & 70 \\
\hline 17 & 69 & M & $\mathrm{W}$ & Buccal mucosa & IV & 68.4 \\
\hline 18 & 63 & $\mathrm{~F}$ & $\mathrm{~B}$ & Buccal mucosa & IV & 70 \\
\hline 19 & 53 & $\mathrm{~F}$ & $\mathrm{~W}$ & Floor of the mouth & II & 72.2 \\
\hline 20 & 64 & M & $\mathrm{W}$ & Oropharynx & IV & 71 \\
\hline 21 & 59 & M & $\mathrm{W}$ & Hypopharyx & IV & 60.4 \\
\hline 22 & 54 & M & $\mathrm{W}$ & Larynx & III & 68 \\
\hline
\end{tabular}

M - male, F - female, B - black, W - white, Gy - grays. 
Bonan PRF, Pires FR, Lopes MA, Hipólito Jr O Di. Evaluation of salivary flow in patients during head and neck radiotherapy. Pesqui Odontol Bras 2003;17(2):156-60.

group was matched by age, skin color and gender. None of the patients had undergone radiotherapy or presented medication-related xerostomia. In the control group, only one salivary collection was performed (Table 2).

For the saliva collection, all patients were instructed to swallow the saliva present in their mouths, and after this step they were asked to put the total saliva produced in glass recipients. The saliva collected was identified and weighed. If patients were wearers of complete dentures or remov-

TABLE 2 - Distribution of patients (group II) according to age, gender and salivary flow $(\mathrm{ml} / \mathrm{min})$.

\begin{tabular}{|c|c|c|c|}
\hline Patients & Age & Gender & $\begin{array}{c}\text { Salivary } \\
\text { collection } \\
(\mathrm{ml} / \mathrm{min})\end{array}$ \\
\hline 1 & 69 & M & 1.9204 \\
\hline 2 & 73 & $\mathrm{M}$ & 0.325 \\
\hline 3 & 52 & $\mathrm{M}$ & 1.1072 \\
\hline 4 & 42 & M & 0.643 \\
\hline 5 & 45 & M & 0.397 \\
\hline 6 & 68 & $\mathrm{M}$ & 0.5065 \\
\hline 7 & 65 & $\mathrm{M}$ & 0.5662 \\
\hline 8 & 66 & $\mathrm{M}$ & 0.4738 \\
\hline 9 & 75 & $\mathrm{M}$ & 0.4752 \\
\hline 10 & 78 & $\mathrm{M}$ & 0.4296 \\
\hline 11 & 73 & $\mathrm{M}$ & 1.402 \\
\hline 12 & 48 & $\mathrm{M}$ & 0.9786 \\
\hline 13 & 47 & M & 0.1646 \\
\hline 14 & 67 & M & 0.066 \\
\hline 15 & 62 & $\mathrm{M}$ & 0.213 \\
\hline 16 & 64 & $\mathrm{M}$ & 0.8546 \\
\hline 17 & 43 & $\mathrm{M}$ & 1.66 \\
\hline 18 & 46 & $\mathrm{M}$ & 0.108 \\
\hline 19 & 61 & $\mathrm{~F}$ & 0.5222 \\
\hline 20 & 62 & M & 1.2612 \\
\hline 21 & 74 & $\mathrm{~F}$ & 0.278 \\
\hline 22 & 56 & M & 0.5004 \\
\hline 23 & 49 & $\mathrm{~F}$ & 0.74432 \\
\hline 24 & 42 & $\mathrm{~F}$ & 0.4626 \\
\hline 25 & 54 & $\mathrm{~F}$ & 0.5366 \\
\hline Average & 59.24 & - & 0.6618 \\
\hline
\end{tabular}

able partial dentures, they were informed to remove their prostheses during the collection.

The weight of each collection was measured and adjusted to flow in $\mathrm{ml} / \mathrm{min}$ for each patient. To classify the salivary flows, values below $0.1 \mathrm{ml} / \mathrm{min}$ were indicative of xerostomia ${ }^{16}$. Twotailed tests were used for evaluation of the salivary flow.

\section{RESULTS}

The regions more affected by the squamous cell carcinomas were floor of the mouth $(18.2 \%)$, buccal mucosa (9\%) and pyriform sinus (13.6\%). The more frequent clinical stages were stage IV (63.5\%) and stage III (27.3\%). The average dose of radiation used for the tumors was of $69.69 \mathrm{~Gy}$. Radiotherapeutic fields involved the parotid glands in all patients, and total doses were higher than the minimum values for permanent xerostomia (Table 1).

Regarding the salivary flow in the control group, the average was $0.6618 \mathrm{ml} / \mathrm{min}$ (Table 2). In irradiated patients, the average in the first collection was $0.5827 \mathrm{ml} / \mathrm{min}$, being similar to that of the control group, with no statistical difference $(p=0.5366)$. However, these patients presented a significant decrease between the initial collection and collection $2(p=0.0008)$. In addition, this reduction persisted in collection 3. Statistical analysis did not show differences between collection 2 and $3(\mathrm{p}=0.9822)$. The data about the distribution of salivary flows (group I) are shown in Graph 1 and Table 3.

\section{DISCUSSION}

The reduction of salivary flow is an important side effect of head and neck radiotherapy, causing difficulties to chew, swallow, speak and eat ${ }^{5,10,11}$. It

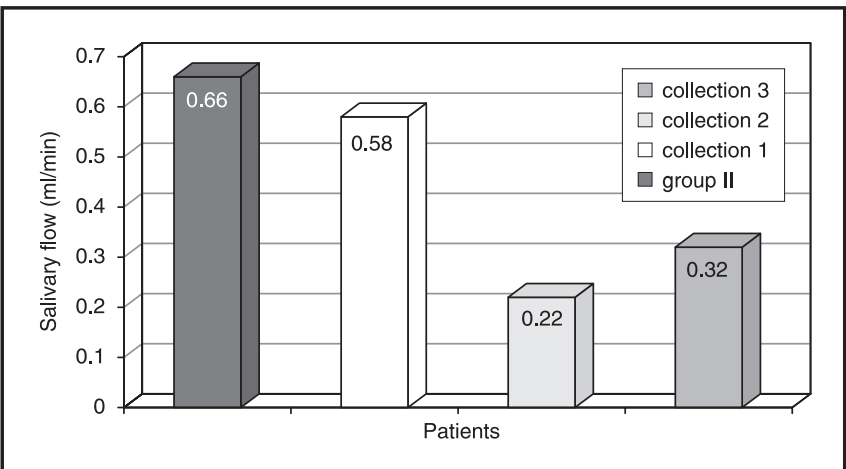

GRAPH 1 - Salivary flow averages (ml/min) in group I (three collections) and group II (control). 
Bonan PRF, Pires FR, Lopes MA, Hipólito Jr O Di. Evaluation of salivary flow in patients during head and neck radiotherapy. Pesqui Odontol Bras 2003;17(2):156-60.

TABLE 3 - Distribution of patients (group I) according to salivary collections ( $\mathrm{ml} / \mathrm{min})$.

\begin{tabular}{c|c|c|c}
\hline \hline Patient & Collection 1 & Collection 2 & Collection 3 \\
\hline 1 & 0.958 & 0.5908 & 0.3226 \\
\hline 2 & 0.6508 & 0.4914 & 0.4024 \\
\hline 3 & 0.6116 & 0.0956 & 0.0936 \\
\hline 4 & 0.2434 & 0.201 & 0.1766 \\
\hline 5 & 0.87 & 0.2848 & 0.5354 \\
\hline 6 & 0.2676 & 0.2864 & 0.4412 \\
\hline 7 & 0.3164 & 0.0586 & 0.089 \\
\hline 8 & 1.329 & 0.1396 & 0.2164 \\
\hline 9 & 0.8172 & 0.188 & 0.0566 \\
\hline 10 & 0.6742 & 0.2716 & 0.1335 \\
\hline 11 & 0.2422 & 0.3218 & 0.2692 \\
\hline 12 & 0.0924 & 0.2272 & 0.0018 \\
\hline 13 & 1.6884 & 0.1348 & 0.1986 \\
\hline 14 & 0.2322 & 0.0158 & 0.749 \\
\hline 15 & 1.1346 & 0.1868 & 0.2796 \\
\hline 16 & 0.1736 & 0.3248 & 0.0616 \\
\hline 17 & 0.3449 & 0.304 & 0.27 \\
\hline 18 & 0.3756 & 0.0394 & 0.0694 \\
\hline 19 & 0.2374 & 0.0232 & 0.1044 \\
\hline 20 & 0.3528 & 0.22316 & 0.1826 \\
\hline 21 & 0.6632 & 0.391 & 0.0988 \\
\hline \hline & 0.544 & 0.2564 & 0.2796 \\
\hline \hline 22 & 0.582705 & 0.229825 & 0.32260 \\
\hline
\end{tabular}

also results in alterations in the oral microbiota as well as in an increase of the risk for the development of dental caries ${ }^{2,9,10,12}$. Patients submitted to radiotherapy present reduction of salivary flow in the first weeks of treatment. In many cases, this reduction becomes irreversible ${ }^{15}$. The sensation of mouth dryness called xerostomia is normally asso- ciated with salivary flow. Normally, the level of salivary flow considered to be xerostomic in non-stimulated saliva is below $0.1 \mathrm{ml} / \mathrm{min}$. In our study, 5 out of 22 evaluated patients $(22.5 \%)$ were classified as xerostomic in collection 2 (during radiotherapy), and 7 patients (32\%) were thus classified in collection 3 (end of radiotherapy).

In the first collection, patients from group I (irradiated) presented average salivary flows similar to those of patients from group II (control). Regarding the second collection of saliva, a significant reduction of saliva was observed. This reduction is in agreement with the fact that radiation applied to the head and neck promotes a decrease of saliva with doses of 20 Gy. It occurs particularly when parotid glands are included in the radiotherapeutic fields ${ }^{14,15}$. However, in our cases, salivary flow did not reach xerostomic levels, which could indicate that, in these cases, xerostomia is more a symptomatic phenomenon, or that the complaints of dry mouth and saliva viscosity are more relevant than the actual quantitative reduction of salivary flows.

In the third collection (end of treatment), salivary flows were low and similar to those of the second collection (during treatment). Some studies have also demonstrated that the salivary flow reduction is more significant in the first two weeks of radiotherapy, without important changes in the 13 following weeks ${ }^{3}$. However, others showed that there is a linear reduction of non-stimulated saliva $^{8}$.

\section{CONCLUSION}

To summarize, our study showed that radiotherapy leads to an important reduction of salivary flow during and after treatment.

\section{ACKNOWLEDGMENT}

We wish to thank the Grant from the São Paulo State Research Foundation (FAPESP, No. 99/1364-7), Brazil.

\section{REFERENCES}

1. Almstahl A, Wikstrom M. Oral microflora in subjects with reduced salivary secretion. J Dent Res 1999;78:1410-16.

2. Blozis GG, Robinson JE. Oral tissues changes caused by radiation therapy and their management. Dent Clin North Am 1968;643-56.

3. Burlage FR, Coopes RP, Meertens H, Stokman MA, Vissink A. Parotid and submandibular/sublingual salivary flow

during high dose radiotherapy. Radioth Oncol 2001;61:271-4.

4. Carl W. Local radiation and systemic chemotherapy: preventing and managing the oral complications. J Am Dent Assoc 1993;124:119-23.

5. Epstein JB, Emerton S, Kolbison DA, Le ND, Phillips N, Stevenson-Moore P, et al. Quality of life and oral function 
Bonan PRF, Pires FR, Lopes MA, Hipólito Jr O Di. Evaluation of salivary flow in patients during head and neck radiotherapy. Pesqui Odontol Bras 2003;17(2):156-60.

following radiotherapy for head and neck cancer. Head and Neck 1999, 21:1-11.

6. Garg A, Malo M. Manifestations and treatment of xerostomia and associated oral effects secondary to head and neck radiation therapy. J Am Dent Assoc 1997;128:1128-33.

7. Gibson G. Identifying and treating xerostomia in restorative patients. J Esth Dent 1998;10:253-64.

8. Henson BS, Eisbruch A, D'Hondt E, Ship JA. Two-year longitudinal study of parotid salivary flow rates in head and neck patients receiving unilateral neck parotid-sparing radiotherapy treatment. Oral Oncol 1999;35:234-41.

9. Holmes S. Xerostomia: aetiology and management in cancer patients. Support Care Cancer 1998;6:348-55.

11. Lopes MA, Colleta RD, Alves FA, Abadde N, Rossi Jr A. Reconhecendo e controlando os efeitos colaterais da radioterapia. Rev Assoc Paul Cirur Dent 1998;52:241-4.

12. Regelink G, Vissink A, Reintsema H, Nauta JM. Efficacy of a synthetic polymer saliva substitute in reducing oral com- plaints of patients suffering from irradiation-induced xerostomia. Quintessence Int 1998;29:383-8.

13. Rothwell BR. Prevention and treatment of orofacial complication of radiotherapy. J Am Dent Assoc 1987;114:316-22.

14. Schubert MM, Izutsu KT. Iatrogenic causes of salivary gland dysfunction. J Dent Res 1987;66:680-8.

15. Scully C, Epstein JB. Oral health care for the cancer patient. Eur J Cancer B Oral Oncol 1996;32B:281-92.

16. Sreebny LM. Saliva in healthy and disease: an appraisal and update. Int Dent J 2000;50:140-61.

17. Weerkamp AH, Wagner K, Vissink A, Gravenmade EJ. Effect of the application of mucin-based saliva substitute on the oral microflora of xerostomic patients. J Oral Pathol $1987 ; 16: 474-8$.

18. Whitmyer CC, Esposito SJ, Terezhalmy GT. Radiotherapy for head and neck neoplasm. Gen Den 1997;45:363-70,

19. Williams DW, Lewis MA. Isolation and identification of Candida from the oral cavity. Oral Dis 2000;6:3-11.

Recebido para publicação em 20/08/02

Enviado para reformulação em 05/02/03

Aceito para publicação em 15/05/03 